\title{
Problem-Based Teaching of Literature
}

\author{
Jela Markušić ${ }^{1}$, Jakov Sabljić ${ }^{1}$ \\ ${ }^{1}$ Josip Juraj Strossmayer University of Osijek, Faculty of Humanities and Social Sciences, Croatia \\ Correspondence: Jakov Sabljić, Josip Juraj Strossmayer University of Osijek, Faculty of Humanities and Social \\ Sciences, Croatia.
}

Received: August 23, 2018

Accepted: January 6, 2019 Online Published: February 15, 2019

doi:10.11114/jets.v7i4.4066

URL: https://doi.org/10.11114/jets.v7i4.4066

\begin{abstract}
The problem-based teaching of literature is a contemporary teaching model that has emerged from the need to overcome the weaknesses of traditional teaching and to increase the efficiency of educational work. Unlike the traditional paradigms that focused on the teacher and the lecturing model of education, the problem-based teaching of literature engages students, places them at the centre of the teaching process, and encourages them to independently define and research the problem. The problem-based teaching of literature is based on the students' active relationship to literary phenomena, while the teacher functions as the initiator and motivator of the students' versatile creations that are reached by solving problem-based tasks. This paper explores the problem-based teaching of literature and presents the results and discussion of the conducted research on the attitudes of Croatian language teachers on the problem-based teaching of literature. Fifty Croatian language teachers participated in the research by filling a survey in an attempt to determine how often the respondents use the problem-based teaching of literature as well as which forms, methods and methods of teaching they use. More specifically, the aim was to determine how teachers see their own role and students' activity in problem-based teaching of literature. In addition, the research sought to find out whether teachers believe that learning outcomes are more successfully achieved in the problem-based teaching of literature and what the reasons for the (un)acceptability of the problem-based teaching of literature are.
\end{abstract}

Keywords: problem-based teaching, literature, students, teacher, teachers' attitudes

\section{Introduction}

\subsection{The Problem-Based Teaching of Literature as a Shift from the Traditional Teaching}

From the perspective of contemporary teaching, the traditional class-subject-lesson system should change and the former encyclopaedic knowledge needs to be replaced by "developing the ability to understand, solve problems, and apply practical knowledge to acquire skills that contribute to the students' quality of life in the contemporary world" (Tot, 2010: 67). Accordingly, a uniformed approach to all students, rigid relationship between teachers and students, reduced student freedom, neglect of independent research work and creativity (Stevanović, 2003: 12), and focus on the content and scope of knowledge (Kajić, 1984: 364) are seen as the main weaknesses, issues, and disadvantages of traditional teaching in fulfilling contemporary teaching tasks. In the book Modeli kreativne nastave [Creative Teaching Models], M. Stevanović (2003: 12) emphasizes that such problems can be solved following a bold view of the future, dispensing with an uncritical imitation of past strategies, and by using contemporary teaching models.

One such contemporary teaching model that has emerged from the need to overcome the weaknesses of traditional teaching and increase the efficiency of educational work (Gajić, 2004: 41) is the problem-based creative teaching methodology system for which numerous terms occur in the scientific literature: problem-based teaching, problem-situation, problem solving, problem-solving teaching, and problem-solving learning. Nevertheless, in contemporary teaching methodology, the problem-based creative methodology system is the most widespread under the term problem-based teaching (Gajić, 2004: 139). In changing the organization of work and approach to teaching contents, the problem-based teaching represents a radical shift in comparison to traditional teaching (Kajić, 1984: 364). In it, teaching is not based on the students' passive observation of the operations performed by the teacher since it establishes an active (thoughtful) attitude toward phenomena, and encourages the students' independent hypothesizing, researching, and problem solving (Rosandić, 1975: 159). 


\subsection{The Importance of Researching Attitudes on Problem-Based Teaching of Literature}

Scientific literature often highlights the advantages of the problem-based teaching and states that it accelerates the development of students' creative and psychological abilities, enables the development of functions such as analysis, synthesis, abstract thinking, generalization, induction, and deduction. In other words, the development of student autonomy, perseverance, persistence, and self-confidence is emphasized (Stevanović, 2003: 209). It also points out that the knowledge gained through problem-based teaching is more long-lasting, i.e. that problem-based teaching increases motivation, intensifies the level of knowledge acquisition (Lazzarich, 2011: 114), as well as develops interest and curiosity, shapes personality, perseverance, and criticism (Obradović \& Pofuk, 2005: 36).

Thus, since the scientific literature states that problem-based teaching positively affects the students, that is, that the problem-creative methodological system extends and deepens teaching objectives and tasks, and thus makes a significant advancement in relation to previous methodical systems, it is necessary to explore whether problem-based teaching of literature is applied in practice. To put it differently, it is necessary to explore the teachers' attitudes on the organization of problem-based literature teaching. The insight into the educational practice is presented by researching data on the frequency of use of problem-based teaching approach, used teaching methods, forms, and procedures, the teachers' view of their role, and the view of the role and activity of students in problem-based teaching of literature, and by delivering data on the reasons for its (un)acceptability.

\subsection{A Short Overview of Scientific Literature}

\subsubsection{On the Problem-Based Teaching of Literature}

In his book Problemska, stvaralačka i izborna nastava književnosti [Problem-Based, Creative and Elective Teaching of Literature], Dragutin Rosandić (Rosandić, 1975: 219) instructs that problem-based teaching began to be applied in the 1960s. Today, such organization of teaching is generally accepted as the highest form of learning (Stevanović, 2003: 209), not based on passive observation of operations performed by the teacher, but on the intellectual, emotional, and fantasy activities of the students. The interest in problem-based teaching has not lapsed since its appearance in the twentieth century, when monographs devoted to problem-based teaching literature began to appear. Methodologists and pedagogues have since then, mostly in their books and articles, highlighted the advantages of such teaching, listed the stages of a lesson within the problem-based teaching system, and proposed methodological problem-based models with specific topics for individual lessons.

Undoubtedly, the problem-based teaching of literature is a dynamic, open, and flexible teaching system (Kajić, 1984: 47) in which the problem-based approach to literary content is used. Namely, it attempts to illuminate the main issue within a certain literary age, the writer's opus, his or her creative stages and those present in a specific literary work. The literary problem is mostly defined in scientific literature as a conceptual, complex issue that has a direct impact on the stimulation of students' interest, their ability to formulate theses, develop contradictory opinions, and independently form their point of view, argumentation, and conclusion. Thus, the learner is not presented with definite conclusions, but the literary problem is emotionally perceived and only then the student tries to solve it on an intellectual level. In the problem-based teaching of literature, the student is introduced to a literary problem that needs to be explored independently and the research of which, according to psychological and pedagogical research studies, acquires a deeper and more intense cognition (Rosandić, 2005: 205).

In solving the problem, the student goes through the five stages of teaching, namely: the problem situation, problem definition, problem-solving methods, independent research work, analysis, correction and supplementation of research results and new tasks for independent work (Rosandić, 1975: 162).

A problem situation functions as the students' motivation and introduces the literary work, i.e. it partially announces the problem. It is "a kind of experience, uncertainty, curiosity, expectation, mental tension, determination to engage in problem solving" (Gajić, 2004: 50). For instance, in the interpretation of Henrik Ibsen's play A Doll's House (1879), the problem situation is created by setting a disputable thesis: Nora is materialist, she pretends to be happy with her family, makes her children feel safe but not loved, and continuously takes on the role of a victim in order to free herself from the burden of family life.

After creating a problem situation that encourages interest and motivation for problem solving, the second stage of the lesson consists in analysing the problem and looking for opportunities to solve it (Rosandić, 2005: 221). That is, the main problems are highlighted and formulated, and research methods are determined. During the analysis of the aforementioned play, students are divided into groups and each group receives problem-based tasks, such as the following (Naplačić, 2012: 50-51):

- Describe the image of the Helmer family in relation to society and in relation to itself - the positive and the negative sides. 
- Determine the similarities and differences in the motherhood of Anna Karenina, Emma Bovary, and Nora.

- In addition to duties of a husband and father, what else makes Torvald similar to Charles Bovary and Alexei Karenin?

- Is Ibsen's drama a kind of myth on the beauty and ideal nature of family life? Explain in terms of the following dimensions: Nora $\rightarrow$ a daughter, Nora $\rightarrow$ a wife, Nora $\rightarrow$ a mother, Nora $\rightarrow$ an emancipated woman.

- Is a woman who abandons her children in pursuit of self-actualization a sinner or a sufferer?

- What do we learn about the atmosphere in the Helmers' family home from dramatic dialogues, monologues, and stage directions? What changes toward the end, and what remains the same?

- Explain the differences and similarities between a doll as a symbol of beauty and Nora's character, wherein the doll is a synonym for emotional vanity and coldness.

- Is Dr Rank a true friend of the Helmer family or a man with hidden intentions?

- Why did Nora not “use” Dr Rank's love to solve her financial problems as well as to save her marriage?

- Can the marriage in Ibsen's play be called a contract? Why?

- Explain the relationship between Nora's immaturity and the maturity of Mrs Linde.

In the third stage, the students' independent research work is organized. Students use different methods and procedures to solve or pose new problem-based questions and alternatives, they state certain facts in support of problem-solving, indicate problematic relationships, seek arguments for the set hypotheses, or compare problems with similar ones they have already solved (Rosandić, 2005: 221). In the fourth stage of the lesson, students find evidence for the set hypotheses and deliver a conclusion (Rosandić, 2005: 221). In Problemska nastava književnosti u teoriji $i$ praksi [Problem-Based Teaching of Literature in Theory and Practice], Gajić (Gajić, 2004: 121) points out that very often the polemical attitudes arise at this stage, which leads to the development of the students' critical thinking. Accordingly, during the analysis of Ibsen's A Doll's House, students are shortly presented with the postulates of contemporary feminism and the development of feminist ideas. The following issues are therefore posed:

- Why do feminists consider Nora to be their paragon?

- Why is Nora important for the emancipation of women through literature mediation?

- Does emancipation focus exclusively on women and their needs?

- A woman's absence from home creates a void that is difficult or impossible to fulfil!

- Feminism does not accept the claim that a woman is subject to man!

- Feminism attempts to eliminate the differences between men and women!

- Are contemporary women happier than their mothers and grandmothers were?

- Has feminism changed the quality of male-female relationships and the quality of a woman's life in general?

Students associate these claims with Ibsen's play by commenting, seeking clarification, offering positive and negative views on the statements, providing arguments from the text of the play, and independently concluding in what way Ibsen's play is current (Naplačić, 2012: 52).

In the final stage of the classroom lesson of problem-based teaching of literature, the students are given new tasks for independent work that can be solved at home. The aim of these tasks is to expand and deepen the problem-based approach to the work accomplished in school and to satisfy the affinity of students to the fullest (Kajić, 1984: 62). At this stage of the classroom lesson, the students' creativity is attempted to be engaged. Creative tasks for independent students' work can include content and formal elements of the work, and the results should contain as many original solutions as possible. For example, literary text may be the basis for the screening, film or radio adaptation, or it can be upgraded and transformed into another type of literary work (Kajić, 1984: 62). In the interpretation of Ibsen's $A$ Doll's House, students are again divided into groups and each group has its own name. The first group consists of two marriage counsellors, the second group includes financial advisers, the third group are psychoanalysts, the fourth group are family friends, the fifth group is the society, and the sixth group are the Helmers' children. Students engage in role-play for counselling or criticizing the Helmer family, depending on which group they belong to. After the students complete the task, each student from each group expresses their opinion depending on their position, but from the perspective of the assigned role. Interaction takes place between all the groups because individual counsellors complement each other, while others have contrasting opinions (Naplačić, 2012: 47). 


\subsubsection{The Role of Students and Teachers in Problem-based Teaching of Literature}

Unlike traditional teaching, in which the teacher is at the centre of the teaching process, and the one who transfers the knowledge ex cathedra, while the student is a passive recipient of information, in problem-based teaching of literature, the teacher imposes new obligations and requires a more developed degree of expertise and methodology (Rosandić, 1975: 170). The student is an active participant of the educational process in which independence and creativity are encouraged.

Additionally, the role of the teacher has been significantly altered in the problem-based teaching of literature. In the doctoral dissertation Problemska nastava književnosti kao metodički sustav [Problem-Based Teaching of Literature as the Methodological System], R. Kajić (Kajić, 1984: 36) states the following: "The lecturer, whose word is a source of knowledge and who has controlled the memorized content, has different, more diverse, and significant tasks in problem-based teaching." On the one hand, the teacher's tasks and functions in the problem-based teaching of literature are the organization and realization of teaching contents and tasks, motivation of students, formulation of actual problems, and the training of students for an active use of different information, laws, principles, rules and sources of knowledge (Stevanović, 2003: 209), as well as providing the necessary assistance, which must be given in a natural, logical, and unobtrusive way to determine and evaluate the effects of student activity (Kadum-Bošnjak \& Peršić, 2007: 76). On the other hand, the students' task is to actively participate in the educational process. Kajić (Kajić, 1984: 49) argues that the problem-based teaching of literature encourages students to approach the literary work and other artistic, cultural, and social phenomena actively, makes them active readers and speakers, and motivates them for creative activity and the adoption of scientific and aesthetic criteria.

\subsubsection{Characteristic Methods and Procedures of Problem-Based Teaching of Literature}

Literary education implies different methods that need to be harmonized and connected, depending on the content and educational teaching tasks (Rosandić, 2005: 271). The choice of method depends on the purpose of teaching, specificity of the teaching content, the degree of students' maturity and autonomy, and the correct choice of teaching methods contributes to dynamism and rationalization as well as influences the results of the educational process (Kajić 1984: 34). Rosandić (Rosandić, 1975: 167) emphasizes that problem-based teaching introduces such research methods that affirm the independent, research, and creative work of students, and the characteristic methods in problem-based teaching of literature are: heuristic conversation, creative (problem-based) reading, problem solving, research method, and problem-based creative tasks (Kajić, 1984: 27).

Heuristic talk denotes the teacher's questions that encourage students to think and speak, and that are productive only if they provoke curiosity, research attention, independency, and willingness to solve a problem (Gajić, 2004: 132). The method of creative text reading provides students with independency in exploring a text as well as with opportunities for an individual and creative approach (Rosandić, 1975: 168). The creative reading of the literary text puts the student in the position of a critic who emotionally experiences the situations in the work, who imagines the world that appears in the work, understands the content and the language of the work, and states his or her own opinion on the work (Gajić, 2004: 130). It is a common practice to associate the teachers' speaking activity with the method of oral presentation, but in the problem-based teaching of literature, the students' oral presentation becomes increasingly important. Kajić (Kajić, 1984: 28) highlights that teachers in problem solving situations only demonstrate the path to knowledge, i.e. that they provide information that enables students to acquire new knowledge. In this way, the student has a range of possibilities to engage and determine the rhythm of researching the problem.

Students are at all times allowed to "intervene," that is, to supplement the teacher's presentation, expand, conclude, problematize, compare, and associate it with something else (Kajić, 1984: 29). The teacher's presentation is thus a "respite" between individual student activities during a lesson and refers to directing, commenting, and synthesizing (Kajić, 1984: 252). The research method presents the highest level of independence in which the student approaches the research work of a scientist. In other words, the student, in exploring various literary problems that may be related to the ideological-thematic and stylistic-compositional level of the literary work (Rosandić, 1975: 169), goes through all the stages of research: defines the problem, develops a research plan, sets the hypothesis, determines the way of verifying it, and draws conclusions and opinions (Rosandić, 1975: 168).

Kajić (Kajić, 1984: 33) states that the method of problem-based creative tasks affirms those tasks involving elements of the problem-based and creative approach, that is, that the teacher, by means of this method, aims to achieve that the various activities involving creative interventions highlight the student's critical attitude toward the problem and its argumentation. Stevanović (Stevanović, 1999: 246) notes that the degree of creative possibilities depends not only on the student's giftedness, spontaneity, and intuition, but also on the ways of organizing educational work. In teaching literature, it is important for the teacher to guide the student while deciphering the literary work, and for the reader with a developed creative attitude not to remain a passive observer of the puzzle before him or her (Stevanović 1999: 246). 


\subsection{Hypotheses}

Considering the aim and research problems, four hypotheses have been set. It should be emphasized that the third and fourth research hypotheses are set with regard to the results of the research study by Dr Vladimir Kadum (Kadum, 2006: 455), according to which learning by problem-solving is more efficient than the traditional method as well as contributes to a more active relationship among the students and a greater motivation for solving tasks. Accordingly, the research hypotheses are as follows: (1) it is expected that the vast majority of respondents will state that they use problem-based teaching of literature often or very often; (2) it is expected that respondents will confirm that they use different forms of organizing student activity as well as characteristic methods and procedures of problem-based teaching of literature (problem-based reading and oral presentation, heuristic conversation, research method, problem-based creative method); (3) it is expected that respondents will state that students' activity in problem-based teaching of literature is higher than in lectures on literature and that learning outcomes are more successful; (4) it is expected that the respondents will indicate the increased student activity, development of critical thinking, and stimulation of student creativity as reasons for the acceptability of the problem-based teaching of literature, and state a more demanding preparation of teaching and the lack of time to perform the problem-based teaching of literature as the shortcomings of problem-based teaching of literature.

\section{Research Method}

The aim of this research was to establish the teachers' attitudes on the problem-based teaching of literature. Therefore, the research problems were as follows: (1) Determine how often respondents use the problem-based approach in the teaching of literature; (2) Identify the respondents' attitudes on the forms, methods, and procedures of problem-based teaching of literature; (3) Identify the respondents' attitudes on the role of teachers and student activity in problem-based teaching of literature, and determine whether learning outcomes are more successful in the problem-based teaching of literature; (4) Identify the reasons for the acceptability and unacceptability of problem-based teaching of literature.

\subsection{Participants}

The research was conducted on a random sample of fifty Croatian language teachers. In the research conducted in May 2018, twenty-nine elementary school teachers and twenty-one secondary school teachers participated in the anonymous online survey on the attitudes on problem-based teaching of literature. The elementary schools included were: Elementary School Dr Franjo Tuđman (Beli Manastir), Elementary School Vidikovac (Pula), Second Elementary School (Vrbovec), Elementary School Dr Andrija Mohorovičić, (Matulji), Elementary School Antun Masle (Orašac), Elementary School Juraj Dobrila (Rovinj), Elementary School Dubova (Karlovac), Elementary School Gola (Gola), Elementary School Grgur Karlovčan (Đurđevac), Catholic Elementary School (Požega), Elementary School Bršadin (Bršadin), Elementary School Dalj (Dalj), Elementary School Darda (Darda), Elementary School Izidor Kršnjavi (Zagreb), Elementary School Tin Ujević (Osijek), Elementary School Srdoči (Rijeka), Elementary School Sveta Klara (Zagreb), Elementary School Matija Antun Relković (Davor), Elementary School Spinut (Split), Elementary School Franjo Krežma (Osijek), Elementary School Ivan Nepomuk Jemeršić (Grubišno Polje), Elementary School Vladimir Nazor (Daruvar), Elementary School Dr Vinko Žganac (Zagreb), Elementary School Zamet (Rijeka), Elementary School Šenkovec (Čakovec), Elementary School Ivan Filipović (Osijek), Elementary School Podmurvice (Rijeka), Elementary School Vežica (Rijeka), and Elementary School Fran Koncelak (Drnje).

The secondary schools included were: School of Tourism, Catering and Commerce (Pula), Tituš Brezovački Grammar School (Zagreb), Marko Marulić Grammar School (Slatina), Technical Secondary School (Virovitica), Dr Antun Barac Secondary School (Crikvenica), Secondary Music School (Varaždin), Isidor Kršnjavi Secondary School (Našice), Matija Antun Reljković Grammar School (Vinkovci), Secondary School of Medicine (Slavonski Brod), Vocational School (Virovitica), Technical School (Slavonski Brod), Stjepa Sulimanac Secondary School (Pitomača), Antun Gustav Matoš Grammar School (Samobor), and Secondary School of Agriculture (Zagreb).

\subsection{Data Collection and Analysis}

The data was collected by means of a survey consisting of ten questions on the respondent's gender, name of the school they work in, data on the frequency of use of problem-based approach in teaching literature, data on the forms, methods, and procedures of teaching, data on the role of teachers and student activity in problem-based teaching of literature, data on the successfulness of the achieved learning outcomes, and data on the reasons for the (un)acceptability of problem-based teaching of literature. 


\section{Results}

In this part of the paper, first the gender of the respondent is determined and then the results on the frequency of using the problem-based teaching of literature, data on the forms, methods, and procedures of work used, data on the role of the teacher and students' activity, data on the successfulness of the achieved learning outcomes in problem-based teaching of literature, and data on the reasons for the (un)acceptability of problem-based teaching of literature.

\subsection{The Analysis of Research Results of the Croatian Teacher's Attitudes on Problem-Based Teaching of Literature}

\subsubsection{The Respondents' Gender}

The first question related to the gender of the respondents. It was found that out of fifty respondents, forty-eight respondents (96\%) were female, while only two respondents (4\%) were male. Figure 1 displays the respondents' gender.

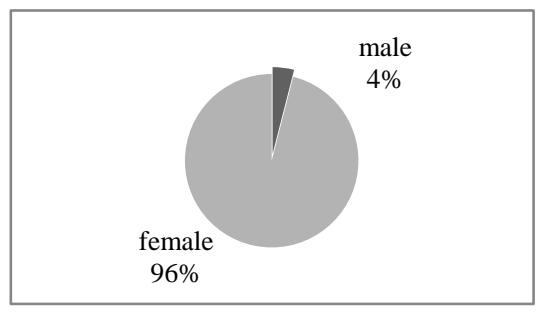

Figure 1. The Respondents' Gender

\subsubsection{The Frequency of Using the Problem-Based Teaching of Literature}

In the third question, the respondents estimated the frequency of use, that is, the application of problem-based teaching of literature in their work. Figure 2 displays the answers of teachers who answered the above-mentioned question with very often, often, sometimes, rarely, or never. It is notable that the majority of fifty respondents, teachers of Croatian language, more specifically, twenty respondents $(40 \%)$, answered that they sometimes use the problem-based teaching of literature. Subsequently, nineteen respondents (38\%) often use the problem-based teaching of literature, while seven respondents $(14 \%)$ use it very often. Furthermore, four respondents $(8 \%)$ answered that they rarely use the problem-based teaching of literature, while none of the respondents $(0 \%)$ opted for the answer never.

Since the research was conducted on the sample of respondents working in elementary and secondary education, it is necessary to compare the results on the frequency of using the problem-based teaching at these two levels. Since the application of problem-based teaching of literature is more complex at the secondary school level, it can be noted that out of seven respondents who answered that they use the problem-based teaching of literature very often, six of them work in an elementary school, and that out of four respondents who answered that they rarely use the problem-based teaching of literature, three are employed in a secondary school.

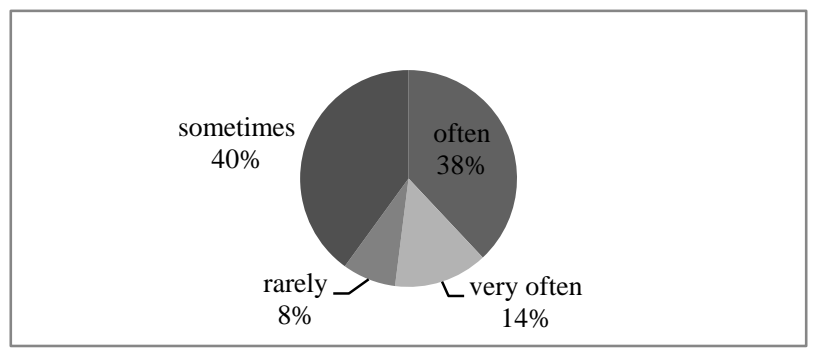

Figure 2. The Frequency of Use of the Problem-Based Teaching of Literature

\subsubsection{Forms of Work}

Based on the answers shown in Figure 3, the majority, that is fourteen respondents (29\%), stated that they apply all forms of work (frontal work, individual work, working in pairs, and group work) in problem-based teaching of literature. Group work is used by eleven respondents (23\%), while group work in combination with working in pairs is applied by seven respondents (14\%). Working in pairs is applied by five respondents (10\%), while other respondents $(20 \%)$ combine different forms of work. The combination of individual work, working in pairs, and group work is used by three respondents, a combination of group work and frontal work is used by one respondent, a combination of group and individual work is used by three respondents, and frontal and individual work is combined by three respondents. Two respondents (4\%) stated that they do not systematically apply the problem-based teaching of literature and did not offer an answer on the used forms of work. 


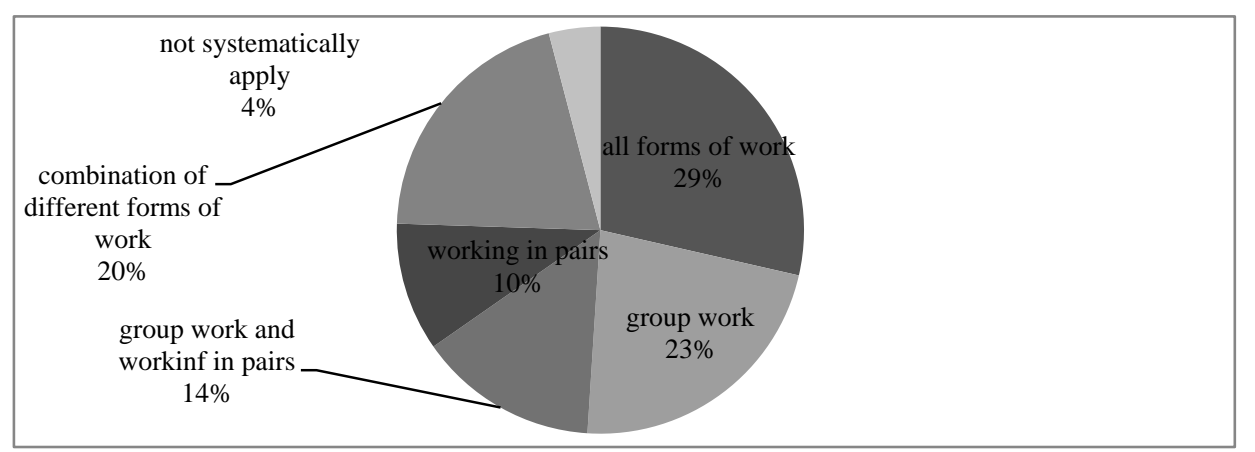

Figure 3. Teachers' Answers on the Use of Forms of Work in Problem-Based Teaching of Literature

\subsubsection{Teaching Methods and Procedures}

Forty-two respondents (84\%) answered the question on the use of methods and procedures in the problem-based teaching of literature, while six (12\%) respondents did not answer it. Two respondents (4\%) stated that they do not systematically apply the problem-based teaching of literature. The teachers offered different answers to this question since, due to their diverseness, they are very difficult to categorize, but one could say that the speaking methods and procedures were found to be the most fruitful methods and procedures, therefore the teachers stated that they most frequently use the following: heuristic conversation, debate, and oral presentation. Also, the methods and procedures used by teachers are the textual methods and procedures, i.e. methods of writing, working on the text, and double diary. Some of the answers referred to the method of six thinking hats, hot chair, courtroom, text dramatization, and an interview with a literary figure.

\subsubsection{The Role of the Teacher}

Teachers have confirmed that the teacher's role in the problem-based teaching of literature has changed considerably when compared to traditional lectures. As the scientific literature constantly reminds that in the problem-based teaching, the teacher is a motivator, organizer, and a conductor of educational work, all the teachers' answers refer to guiding the students' work, coordinating a classroom lesson, preparing assignments for a lesson, encouraging students to think and creatively solve the issue before them.

It is worth pointing out a response that summarizes all the teachers' answers to this question: "Problem-based teaching imposes the role of a teacher in organizing the classroom lesson. The greatest role is the preparation and organization prior to the lesson, while during the lesson, the teacher has the role of a guide, mentor, and person who encourages and directs the students, and poses additional questions."

\subsubsection{Student Activity}

In relation to the question: "Do you agree with the statement that in the problem-based teaching the students are more active and willing to cooperate in a traditional lecture?" twenty-four respondents (48\%) answered that they completely agree with the given statement. Twenty respondents (40\%) answered that they somewhat agree with the given statement, while five respondents (10\%) answered that they neither agree nor disagree with the statement. One respondent (2\%) somewhat disagrees with the statement, while none of the respondents (0\%) opted for the answer I completely disagree.

Forty-seven respondents gave an explanation, stating that the main reasons for a greater activity of students in problem-based teaching of literature when compared to lecturing is that the traditional lectures are nor interesting, while the problem-based teaching of literature activates and makes the teaching content more dynamic, accessible, and interesting.

Some of the representative answers to the above-mentioned question need to be mentioned: Working atmosphere is more relaxed, students talk to each other, the tasks are always such that everyone in the group work has their role, and they are more interested. / During frontal work/lecturing, students only listen and write, while in problem-based teaching they think, analyse, synthesize, and develop critical thinking.

Certain teachers who somewhat agree or somewhat disagree with the statement that the students are more active in the problem-based teaching of literature explain their attitude by stating the fact that students have underdeveloped communication skills and cannot express their opinion, which makes them unable, in their opinion, to actively participate in the problem-based teaching of literature. 


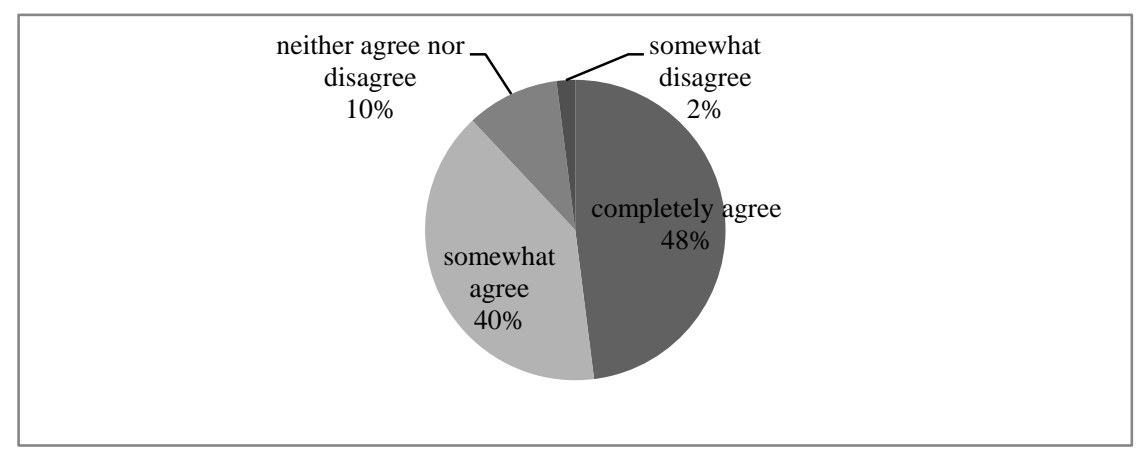

Figure 4. Teachers' Attitudes on Student Activity in Problem-Based Teaching of Literature

\subsubsection{Successfulness of Learning Outcomes}

Figure 5 shows the teachers' answers to the question on the successfulness of the outcomes in problem-based teaching of literature. It is notable that thirty-three teachers $(66 \%)$ answered that they agree with the statement that learning outcomes are more successful in problem-based teaching of literature. Furthermore, ten teachers $(20 \%)$ answered that they neither agree nor disagree with this statement. Finally, seven teachers (14\%) answered that they disagree with the statement that the learning outcomes are more successfully achieved in problem-based teaching of literature.

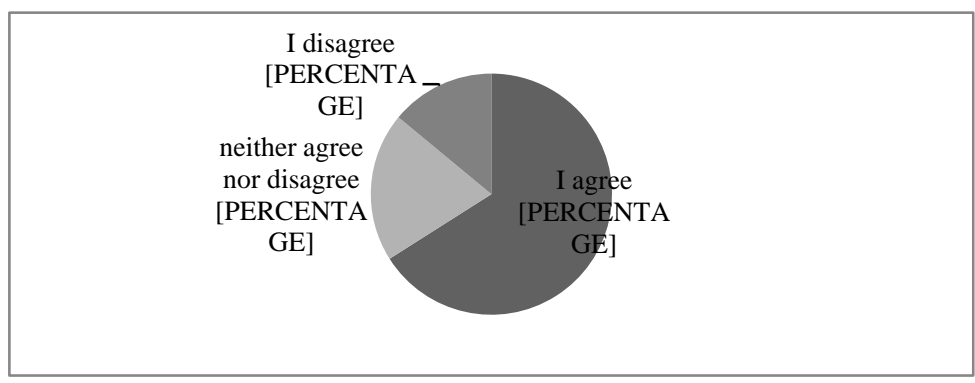

Figure 5. Teachers' Attitudes on the Statement that Learning Outcomes are More Successful in Problem-Based Teaching of Literature

Teachers have supported the statement by answering that learning is easier, faster, and more interesting as students are more interested in problem-based teaching of literature. As reasons for disagreeing with the statement, the teachers have pointed out that the methodology system in the focus of research has no impact on the success nor feasibility of the outcomes. Those who neither agree nor disagree state that the students differ and that each topic requires a different approach.

\subsubsection{Reasons for Acceptability of Problem-Based Teaching of Literature}

Teachers have confirmed that problem-based teaching of literature is an acceptable methodological system. As reasons for the acceptability of the problem-based teaching of literature, teachers have included those that can also be found in scientific literature when it comes to advantages of the problem-based teaching. Namely, teachers emphasized the greater interest and activity of students, development of students' critical thinking and communication skills, encouraging curiosity and exploratory thinking, developing love of reading, and developing the skills of connecting intrasubject and intersubject teaching topics.

\subsubsection{Disadvantages of the Problem-Based Teaching of Literature}

The last question in the survey concerned the teachers' attitudes on the disadvantages of the problem-based teaching of literature, and in Figure 6, it can be seen that nineteen teachers (38\%) indicated that the problem-based teaching had no disadvantages, while thirty-one teachers $(62 \%)$ found that problem-based teaching of literature has its shortcomings.

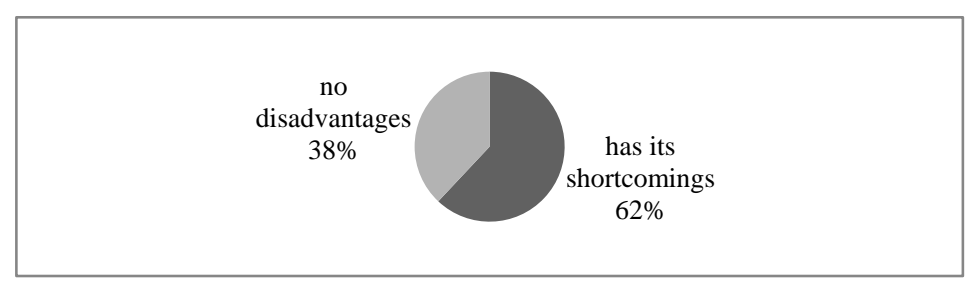

Figure 6. Teachers' Attitudes on the Disadvantages of Problem-Based Teaching of Literature 
As the major shortcomings in problem-based teaching of literature, teachers have indicated the lack of time to prepare the classes, and greater demands on teaching preparation - such an approach requires significantly more effort and a more extensive knowledge. In addition to the lack of time to perform and prepare such classes as well as a greater effort in preparing them, teachers have also referred to the lack of equipment, an increased number of students in the classroom, students' lack of discipline, ignorance, unpreparedness, and poor previous knowledge. The teachers emphasized that students did not adopt certain literary terms in a timely manner and that they were not able to argue and synthesize their attitudes, due to which it is very difficult to apply the problem-based teaching of literature.

\section{Discussion and Conclusion}

The paper presents the results of research conducted in order to explore the teachers' views on problem-based teaching of literature. The research carried out on a sample of fifty Croatian language teachers shows that teachers mostly use group work and heuristic conversation as their teaching methods. It should be emphasized that none of the respondents answered that they use only frontal work (lecturing) when it comes to forms of work, which confirms that teachers have accepted their role as motivators and teaching guides as well as recognized the importance of involving students in the problem-based teaching of literature.

According to the respondents' opinions, students are considerably more interested and motivated in the problem-based teaching of literature than they are in traditional lectures on literature. It is precisely this reason that the respondents referred to as the cause of more successful achievements or learning outcomes in problem-based teaching of literature when compared to traditional lectures. Additionally, the development of critical thinking, creativity, and independence are the main characteristics that the respondents see as the advantages of problem-based literature teaching. As the scientific literature constantly emphasizes that the students' increased activity helps them acquire higher-quality and longer-term knowledge, $88 \%$ of the respondents agree (48\% completely agree and $40 \%$ somewhat agree with the statement) that students are more active and willing to cooperate in problem-based teaching of literature than in traditional lectures on literature. This results points to the need for applying problem-based teaching of literature.

As the disadvantages of problem-based teaching of literature, respondents indicated the lack of time for teaching and a greater need for the preparation of teaching. Therefore, although the teachers have listed considerably more advantages of the problem-based teaching of literature, perhaps these shortcomings are to blame for those who answered that they sometimes use the problem-based literature. However, the results according to which none of the teachers answered that they never use the problem-based teaching of literature shows that they recognize the importance of problem-based teaching of literature in comparison to other methodological systems, such as the interpretation and analysis system, the correlation-integration system, or the analytical-explicative system.

The results also show that the problem-based teaching of literature is more often used in elementary education, but the final conclusion on the use of problem-based teaching of literature in both elementary and secondary school could only be provided with more favourable methodological possibilities and the involvement of a larger number of respondents.

The results obtained mainly confirm the researchers' hypotheses that have been set up with respect to the researched and relevant scientific literature on the frequency of use of problem-based teaching of literature, the manner of organizing teaching work, the role of students and teachers, the successfulness of learning outcomes, and the advantages and disadvantages of the problem-based teaching of literature. The obtained and evaluated results, therefore, refer to further reflection on the methodological theory and teaching practice in order to create a more effective learning process.

\section{Works Cited}

Gajić, O. (2004). Problemska nastava književnosti u teoriji $i$ praksi. Rezultati eksperimentalnih istraživanja [Problem-Based Teaching of Literature in Theory and Practice. The Results of Experimental Research Studies]. Novi Sad: Filozofski fakultet Novi Sad.

Kadum, V. (2006). Učinkovitost učenja rješavanjem problemskih zadataka u nastavi [The Efficiency of Learning through Problem-Solving Tasks in Teaching], Napredak, 147(4), 455-462.

Kadum-Bošnjak, S., \& Peršić, I. (2007). Neki pogledi na ulogu učitelja i položaj učenika u rješavanju problemskih zadataka [Some Views on the Role of the Teacher and the Position of the Student in Problem-Solving Tasks], Metodički obzori, 2(1), 73-80.

Kajić, R. (1984). Problemska nastava književnosti kao metodički sustav. Doktorska disertacija [Problem-Based Teaching of Literature as the Methodological System. Doctoral Dissertation]. Zagreb: Filozofski fakultet Zagreb.

Lazzarich, M. (2011). Stvaralački pristup književnome djelu u sustavu problemske nastave [Creative Approach to Literary Work in the Problem-Based Teaching System], Metodički obzori, 13, 6(3), 111-125.

Naplačić, A. (2012). Problemski pristupi „,Ani Karenjinoj“, ,, Gospođi Bovary“i „,Nori“. Diplomski rad [Problem-Based 
Approach to Anna Karenina, Madame Bovary and A Doll's House. Master's Thesis]. Osijek: Filozofski fakultet Osijek.

Obradović, M., \& Pofuk, L. (2005). Problemska nastava [Problem-Based Teaching], Bjelovarski učitelj, 10(3), 36-40.

Rosandić, D. (1975). Problemska, stvaralačka i izborna nastava književnosti [Problem-Based, Creative, and Elective Teaching of Literature]. Sarajevo: Svjetlost.

Rosandić, D. (2005). Metodika književnog odgoja [Methodology of Literary Education]. Zagreb: Školska knjiga.

Stevanović, M. (2003). Modeli kreativne nastave [Models of Creative Teaching]. Rijeka: Andromeda.

Tot, D. (2010). Učeničke kompetencije i suvremena nastava [Students' Competencies and Contemporary Teaching], Odgojne znanosti, 12(1), 65-78.

\section{Copyrights}

Copyright for this article is retained by the author(s), with first publication rights granted to the journal.

This is an open-access article distributed under the terms and conditions of the Creative Commons Attribution license which permits unrestricted use, distribution, and reproduction in any medium, provided the original work is properly cited. 